\title{
Review of Medium Voltage High Power Electric Drives
}

\author{
Lazhar Ben-Brahim ${ }^{* a)}$ Member, Adel Gastli* \\ Teruo Yoshino** Fellow, Tomoki Yokoyama ${ }^{* * *}$ Member \\ Atsuo Kawamura ${ }^{* * * *}$ Fellow
}

(Manuscript received April 28, 2018, revised Sep. 11, 2018)

\begin{abstract}
The field of electric drives in general, and medium-voltage high-power drives in particular, has recently experienced considerable progress. Numerous interesting developments have been reported in the literature. Various reliable, efficient, and cost-effective medium voltage drive topologies, handling high powers up to $120 \mathrm{MW}$, have been proposed in the literature. This paper provides a detailed overview of the current state-of-the-art in medium-voltage high-power drives and the challenges facing them.
\end{abstract}

Keywords: medium voltage electric drives, variable frequency drives, multilevel inverters

\section{Introduction}

Low Voltage (LV) drives have input voltages less than $690 \mathrm{~V}$ and are used for Low-Power (LP) applications, while Medium Voltage (MV) drives are generally covering output power from approximately $200 \mathrm{~kW}$ to $120 \mathrm{MW}$ and using voltages from $2.3 \mathrm{kV}$ to $11 \mathrm{kV}^{(1)(2)}$. Recently, many industrial applications such as refiners, mills, crushers, blastfurnace blowers, gas compressor stations and gas liquefaction plants, require high-power (HP) ratings. Advances in power electronics made the development of HP and MV adjustablespeed electric drives possible for various industrial applications. The main objective of these drives is to control the load speed and/or torque in an efficient and reliable way, without injecting harmonics to the grid.

Electric drives, in general, went through different development eras. In the 1960-70s, electric drives were mainly DC motor based. At that time, AC motor variable-speed drive controls have not been able to go beyond a simple open-loop Voltage/frequency (V/f) control ${ }^{(3)}$. HP AC motors were dominated by Induction Motors (IMs) and Synchronous Motors (SMs) types. In early 1980s, due to the introduction of the microcomputer-controlled PWM power electronics inverters, more advanced and complex AC motor drive controls became possible ${ }^{(4)-(8)}$. However, these advanced and complex control techniques were limited to mainly LP and

a) Correspondence to: Lazhar Ben-Brahim. E-mail: brahim@ qu.edu.qa

* Electrical Engineering Department, College of Engineering, Qatar University

Doha, P.O.Box. 2713, Qatar

** Toshiba Mitsubishi-Electric Industrial Systems Corporation 1, Toshiba-cho, Fuchu, Tokyo 183-8511, Japan

*** School of Science and Technology for Future Life, Tokyo Denki University

5, Senju-Asahimachi, Adachi-ku, Tokyo 120-8551, Japan

**** Department of Electrical and Computer Engineering, Yokohama National University

79-5, Tokiwadai, Hodogaya-ku, Yokohama 240-8501, Japan
LV applications. The HP and MV drives were predominantly based on Load Commutated Inverters (LCI) or Cycloconverters, for applications such as the steel industry (rolling mills). However, the LCI-based drives suffer from drawbacks such as low harmonic torque ripples, complex starting technique, notches in their terminal voltages, and quasisquare wave currents ${ }^{(3)(9)}$. Besides, limitations on the ratings of power-electronic devices have restricted the power capability of the PWM-inverter-based electric drives. This has changed since the apparition of multilevel converters and new devices such as the GTOs and IGBTs, which paved the way for the application of PWM inverters in HP and MV motor drives $^{(1)(3)-(10)}$. Numerous MV inverter topologies were proposed and investigated in the literature since mid-1980s ${ }^{(1)-(10)}$. The efforts in advancing this technology led to the apparition of various topologies of MV drives such as: ${ }^{(2)(10)}$

1) Series connection of LV inverter modules to satisfy the motor voltage and power requirements;

2) Multilevel inverter topology implemented in three or more levels using high power switches;

3) Parallel connection of multilevel inverters which increases the power handling capability; and

4) Multilevel-inverter-based multiphase motor drives.

Beside the focus on inverters' topologies, several other issues (as depicted in Fig. 1) were also investigated in the literature. This paper reviews the state of the art in HP and MV electric drives, highlighting their related challenges and proposed solutions. The paper is organized as follows: section 2 introduces the MV machines; section 3 presents MV drives topologies; Section 4 discusses multilevel inverters for MV drives; section 5 presents multiphase machines and drives; section 6 discusses challenges related to MV drives; section 7 concludes the paper.

\section{MV Motors}

IMs and SMs are dominating the HP and MV drives' applications and the type of motor selection depends on the application requirements, the electric power network 


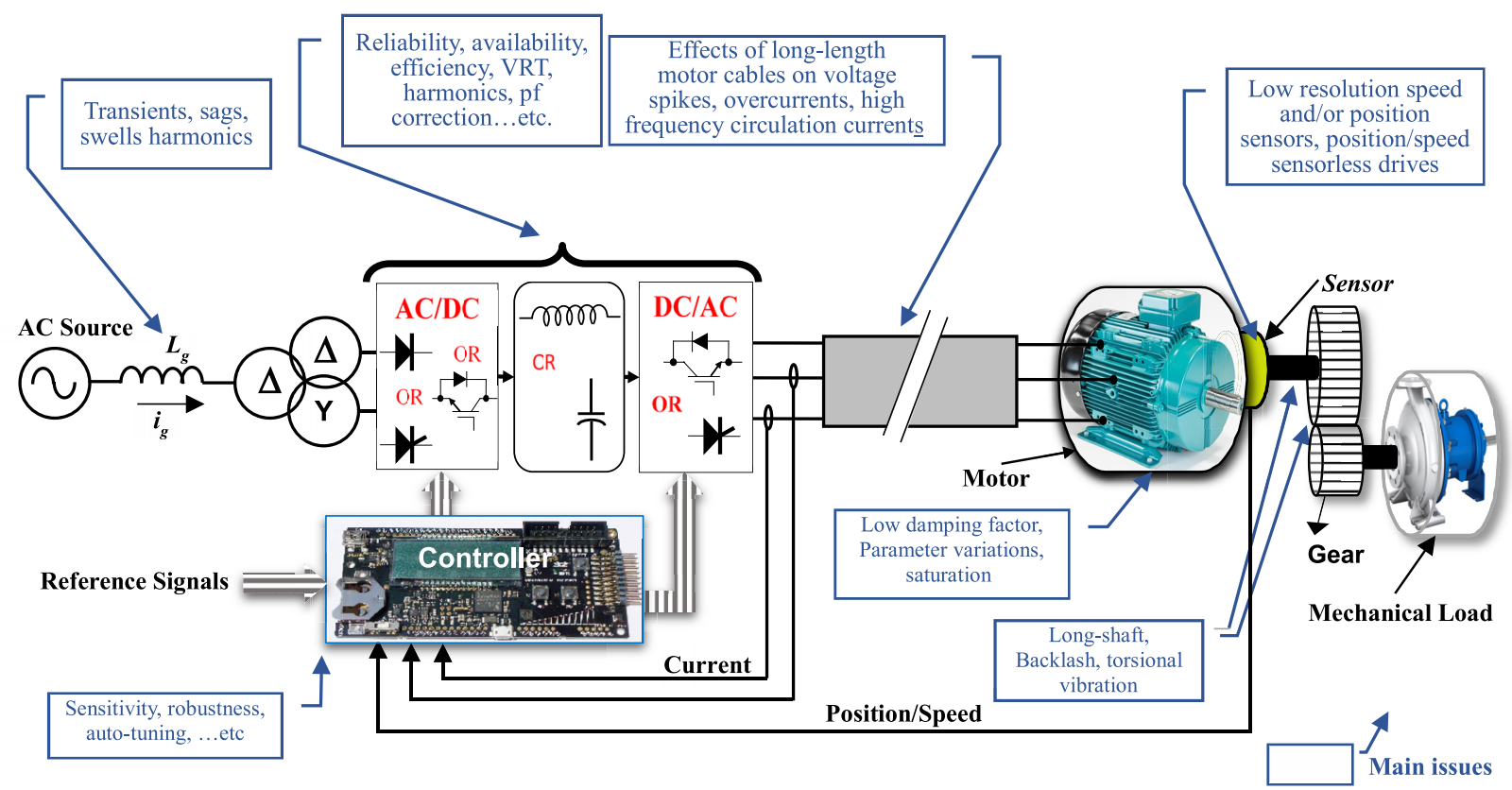

Fig. 1. General drive structure

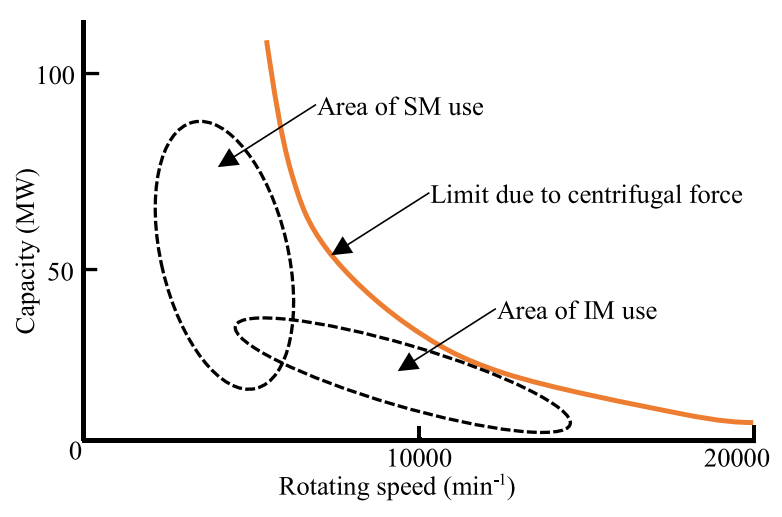

Fig. 2. Areas of IMs and SMs use

specifications and environmental conditions ${ }^{(11)}$. In practice, a detailed analysis and comparison between various types of motors is necessary in order to select a suitable type for a given application. The following general facts are usually considered when selecting a motor type ${ }^{(10)}$ :

- IMs are stiffer, lighter, and more robust because of their simple rotor structures.

- Although SMs need exciter for proper operation, they have higher efficiency, controllable power factor, and constant rotating speed regardless of load variation.

- SMs are preferred for the HP applications since they can produce larger output torque.

Figure 2 shows the SMs and IMs power capacity versus rotating speed, along with their physical limitations ${ }^{(10)}$ due to centrifugal force. Notice that, for high rotating speeds, IMs are preferred, while for larger power capacity, the SMs are better choices.

This can be explained by the fact that the higher is the rotating speed, the higher is the centrifugal force, applied to the rotor, which increases as the rotor radius increases (e.g. case of SMs due to exciter windings). Since the centrifugal force is proportional to the square of the rotor speed and the radius of the rotor ${ }^{(10)}$, larger motor should withstand larger centrifugal force. The rotor should be manufactured with specific types of materials so that it has finite stiffness to withstand the centrifugal force exerted on its rotor and shaft when rotating at high speeds. Therefore, when the rotating speed is very high, a magnetic bearing may be required to levitate the rotor shaft ${ }^{(11)}$ and provide mechanical-contactless rotation; thus, leading to smaller rotational losses and reduced maintenance cost. However, in magnetic levitation, the motor needs a controller to regulate its shaft position ${ }^{(12)(13)}$. Besides, motor cooling consideration is necessary to reduce losses, and explosion-proof construction is also required for use in hazardous locations such as in oil and gas plants ${ }^{(14)}$.

Multiphase motors with more than three phases, in their stators, are becoming a better choice for HP and MV drives' applications. The first 5-phase induction motor drive was proposed in $1969^{(15)}$ for LV applications. The real interest on multiphase machines at that time was due to the $(2 n \pm 1) f$ torque ripples produced by an n-phase machine ${ }^{(16)}$. When using a three-phase inverter six step mode of operation of the torque ripples are of low order frequency which is not desirable. Therefore, the use of a machine with higher phase number looked as the best solution to overcome the low order torque ripples. Henceforth, multiphase drives using various types of inverters were developed ${ }^{(17)-(21)}$. However, with the development of better PWM techniques, this is no more an issue ${ }^{(16)}$. Multiphase machines have several superior features when compared to their three-phase counterparts. These features are: better fault tolerance, smaller wires (low cross section area) used in the winding and hence lower skin effects, lower power per phase and hence lower converter devices' rating. Actual HP and MV industrial drives' development, using multiphase machines for applications, such as in oil pumping ${ }^{(23)}$ and wind energy ${ }^{(24)}$, are also promising. Recently, the focus is on high-reliability, small-size, and faulttolerant configurations development. Moreover, under fault conditions, multiphase motors are more reliable and maintain 
self-starting ability, with minimum effect on the output power level ${ }^{(25)}$. New designs aiming at higher torque density were achieved through stator current harmonic components injection ${ }^{(26)(27)}$. For instance, authors in ${ }^{(28)}$ proposed a fractionalslot concentrated-winding (FSCW) design for five-phase IM that has a better flux-weakening capabilities. Owing to their advantages, the multiphase FSCW surface and interior PM machines are becoming an interesting choice for low voltage applications, especially for electric vehicles ${ }^{(29)(30)}$. However, at high speeds, they suffer from excessive rotor losses due to large spatial harmonic components ${ }^{(31)}$. The fluctuation of magnets price and availability, as well as the need for a higher power wind generation without excess of weight and size, have enforced researchers to explore and develop multiphase (nine-phase) superconducting high power (12 MW) electrical generators for large-scale direct-drive wind turbines ${ }^{(24)(32)}$. The trends in HP and MV multiphase machine technology is expected to grow, and significant new improvements are likely to appear in the near future. More details and progresses in multiphase machine design, modeling, and control can be found in several review papers ${ }^{(33)-(37)}$.

\section{MV Drives}

In the variable frequency operation of HP and MV drives, to match the inverter power to the power of the motor, various topologies or combinations of many inverters are used. Figure 3 shows the main used topologies for high power motor drives. To create an adequate output satisfying high power as well as the medium voltage level of the motor, multiple inverters are used via a parallel connection through balanced reactors at the output (Fig. 3(a)), or through multi-winding transformer at the output (Fig. 3(b)). The two other options to use either multi-phase/multi-winding motor (Fig. 3(c)), or/and multilevel inverter (Fig. 3(d)).

For the first two topologies, installation space is required for the balance reactors or the transformers in addition to the motor and the inverters ${ }^{(10)}$. The combination of multilevel topology based drive system and one of the first two connections can form a very large power drive system ${ }^{(2)(10)}$.

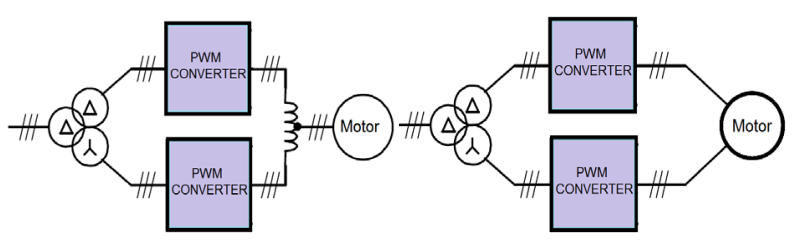

(a) Parallel connection using reactor

(b) Multi-winding motor drive using dual converters

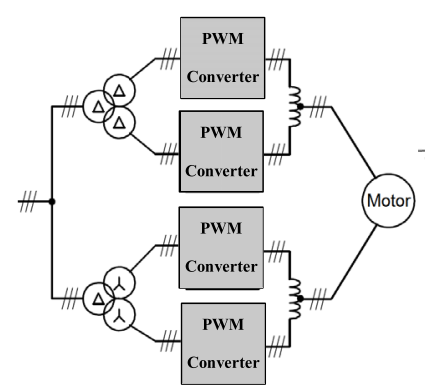

(c) Parallel connection using reactor and Multi-winding motor

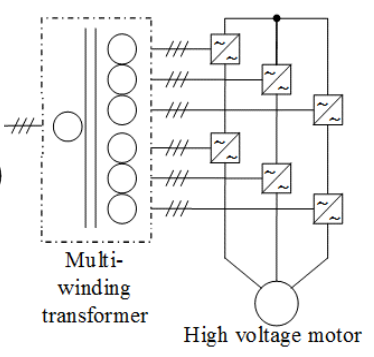

(d) Series connection using multi-cell converter

Fig. 3. Main MV motor drive topologies
Multilevel inverters based drive systems are addressed in section 4.

\section{Multilevel Inverters Topologies for HP-MV Drives}

Multilevel inverters experienced tremendous growth after the introduction of the Gate Turn Off Thyristors (GTO), Insulated Gate Bipolar Transistor (IGBT), Gate Controlled Thyristor (GCT), and Insulated Enhanced Gate Transistor (IEGT) devices.

4.1 Switching Devices The historical progress of the power electronic devices used for HP and MV motor drive is illustrated in Fig. 4. Thyristor, GTO, IGBT, IEGT and GCT are the main power electronics components used in the MV and $\mathrm{HV}$ inverters construction. The first released high power devices were the thyristor. In 1990s, Thyristors were able to handle several $\mathrm{kV}$ and several $\mathrm{kA}$ power.

Transistors are the second developed devices and in the 1980s were released for high power applications. IGBTs were developed to handle higher voltage than the conventional transistor. A continuous progress of IGBT technology has led to the commercialization of its $6^{\text {th }}$ generation and the development of the enhanced IEGT, which can handle larger range of current (few kAs) and low voltage drop by the injection enhanced effect ${ }^{(38)}$. All the devices from GTO to IEGT were made of silicon wafer. New devices, with better performances, were developed using Silicon Carbide (SiC) wafer ${ }^{(38)}$. Although, presently the $\mathrm{SiC}$ device development is for low power and low voltage applications, the $\mathrm{SiC}$ material exhibits better performance than the silicon one, especially for high voltage and high current applications ${ }^{(40)(41)}$. $\mathrm{SiC}$ switching devices can operate at higher switching frequencies while exhibiting lower switching losses. Many companies are working hard to develop high-voltage and highcurrent switching devices. The successful development of inverters for large-capacity AC motor drives rated at MW ranges using this switching device is considered as a matter of time ${ }^{(42)}$. New progress in power semiconductor devices will be the key element to achieving MV drives up to endusers' expectations, such as simplicity, greater functionality, and better reliability.

4.2 Multilevel Topologies Although the concept of multilevel converters has been first introduced in $1975^{(43)}$, it was only in the late 1980s, early 1990s that the multilevel PWM inverters topology was used for PWM electric drives with higher power capability ${ }^{(44)}$. The multilevel era began with the Neutral Point Clamped (NPC) three-level converter $^{(45)}$. Successively, various new topologies of multilevel

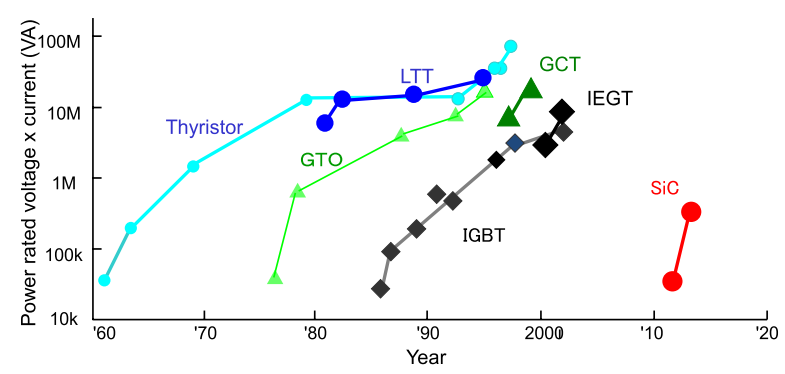

Fig. 4. Development of semiconductor switching device 
converters have been developed ${ }^{(46)-(55)(61)-(94)}$. The output voltage, of multilevel converter, is mainly obtained by appropriately cascading several individual DC voltage sources. The synthesized voltage waveform has a staircase shape, which becomes closer to its sinusoidal reference when a higher number of levels (stairs) is used. The main advantages of such converters over conventional two-level converters are the low harmonic distortion of the generated output voltage, low electromagnetic emissions, high efficiency, the capability to operate at higher voltage ranges, and modularity. In many cases, capacitors can be used instead of the DC voltage sources. In order to achieve high voltage at the output of the inverters, the power electronics switches' controls are synchronized to aggregate these multiple DC voltage sources. However, the rating of the switching devices depends on the individual DC voltage source from which they are powered. The multilevel inverter uses low voltage steps to produce a staircase AC output terminal voltage waveform. These low voltage steps make a significant contribution to mitigating the so-called " $d v / d t$ stresses" in a broad sense of the equipment and, therefore, reduce the long-cable effects and the electromagnetic compatibility (EMC) problems. Furthermore, they produce smaller Common-Mode (CM) voltage and, therefore, reduce the stress on the motor bearings. Advanced PWM techniques can also further reduce the CM voltage ${ }^{(95)}$. Beside the excellent output waveforms, input currents drawn from the grid have lower distortions. Multilevel converters can operate at lower switching frequencies, which results in higher efficiency of the overall drive system. Applications of multilevel inverters for MV drive systems ${ }^{(78)-(102)}$ and to power systems ${ }^{(105)-(107)}$ are becoming widespread. A quiet large number of multilevel converter topologies have been proposed since 1996. Most of these proposed multilevel converters are based on the three following basic topologies:

1) Neutral Point Clamped (NPC) or diode clamped inverter $^{(45)}$

2) Cascaded H-Bridges (CHB) inverter ${ }^{(49)-(54)}$

3) Flying Capacitors (FC) inverter ${ }^{(46)-(48)}$

4) Modular Multilevel Converters (MMC) ${ }^{(54)-(56)}$

5) Multilevel Matrix Converter ${ }^{(57)-(60)}$.

For proper operation of these converters, several PWM control techniques were developed. Four main categories of PWM exist: sinusoidal pulse width modulation (SPWM), space vector modulation $(\mathrm{SVM})^{(62)(63)}$, selective harmonic elimination (SHE-PWM) ${ }^{(64)}$ and discontinuous PWM (DPWM) ${ }^{(65)(77)}$. For more information on multilevel inverters, a survey of topologies, controls, and applications are published in ${ }^{(78)(79)}$.

4.2.1 NPC Inverter based MV Drives Many drives based on NPC inverters have existed since early 1990s ${ }^{(3)-(10)(44)}$. A high power 5-level motor drive topology that can handle up to $30 \mathrm{MW}$ capacity, was introduced using the NPC as a cell, as shown in Fig. 5(a) ${ }^{(2)}$. Each phase of the motor is powered by a single-phase inverter consisting of two legs of a 3-level inverter.

A $7.2 \mathrm{kV}, 30 \mathrm{MW}$, 5-level drive based on Fig. 5(a) topology was implemented and constructed as shown in Fig. 5(b) which is available in the market. Low number large-capacity semiconductor switching devices, GCT, are used. The high voltage, large capacity drive is using a simple circuit topology

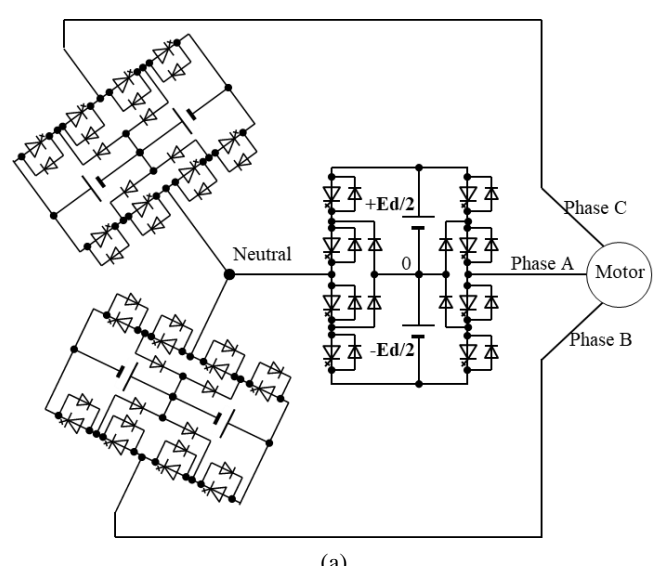

(a)

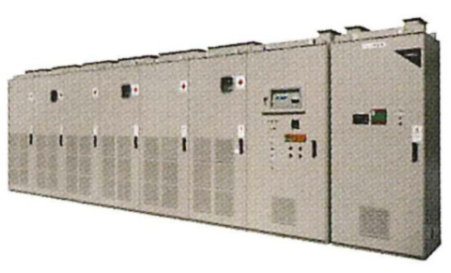

(b)

Fig. 5. (a): Circuit configuration of star-connected 5level inverter ${ }^{(99)}$, (b): $30 \mathrm{MW}$ NPC cell-based 5-level inverter set

and a small number of devices, which improved the converter reliability ${ }^{(47)}$. The resulting line-to-line voltage has nine levels. By paralleling four $30 \mathrm{MW}$ inverters through the reactors, 120 MW drive system can be realized ${ }^{(2)}$.

4.2.2 CHB Inverter based MV Drives CHB multilevel inverter topology is made of several series connected cells. Each cell is composed of a diode rectifier, a DC link capacitor, and a single phase H-Bridge inverter as shown in Fig. 6(a). The series connection of the cells yields high output voltage with staircase waveforms. Figure 6(b) shows the output voltage waveform of the drive inverter with 6 cells in series. By increasing the number of levels in the converter, the output voltage has more steps generating a near sinusoidal waveform. A multi-winding transformer is used to offer insulation among cells and will not inject any lower order harmonics into the grid due to the proper phase shifting between phases of windings ${ }^{(10)(49)-(54)}$.

When required, CHB drive inverters can use bypass switches to improve the reliability of the system. However, if this switch is not well designed it will lead to unreliable system $^{(81)}$. The use of film capacitors in the DC-link by the advanced paralleling design is expected to further improve the reliability of the drive ${ }^{(81)}$.

4.2.3 MMC based MV Drives Several researches are focusing on MMC for high power motor drive applications ${ }^{(88)}$. Due to the floating capacitor voltages, it is known that, at low speed operation, MMC suffers from a power imbalance between the upper and lower arms. This results in a limited use (pumps, compressors and fans) of MMC for drives ${ }^{(82)}$. Several techniques were proposed to overcome this imbalance problem ${ }^{(80)(84)(88)(90)(91)}$. These techniques are based on redistributing power between the upper and lower arms by injecting a common-mode voltage and circulating current to the three phases of the converter ${ }^{(80)-(84)}$. Authors 


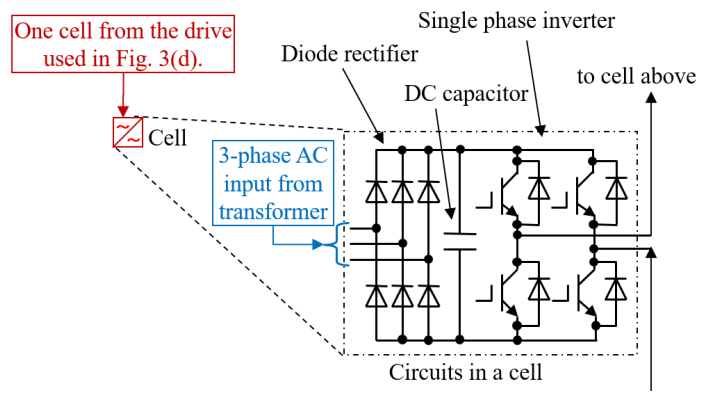

(a)

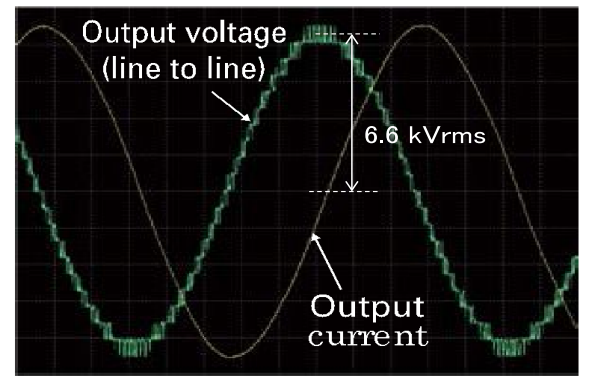

(b)

Fig. 6. (a): Typical full bridge cell configuration used in Fig. 3(d), (b): Line-to-line output voltage and current waveforms of 6-cell configuration used in Fig. 3(d)

in ${ }^{(88)}$ improved these techniques and were able to reduce the peak value of circulating current by up to $50 \%$. However, the techniques proposed so far, improve the power imbalance in detriment of larger common-mode voltage that may harm the motor bearings ${ }^{(89)}$. Other techniques, are based on modified control strategy ${ }^{(90)}$ to reduce the power imbalance and to allow larger capacitor voltage ripples at low speed operation without injecting common mode voltage ${ }^{(89)(90)}$. This technique is effective in the medium to high speed ranges. At low operating speed, the common-mode voltage and circulating current can hardly be avoided ${ }^{(91)}$. Another topology called active cross connected MMC (AC-MMC) is proposed to mitigate the common-mode voltage for medium-voltage motor drives in the full motor speed range. The imbalance of power is reduced through a physical path formed by the cross-connected branch. The proposed topology makes the MMC more complex and expensive ${ }^{(92)}$. In summary, more research efforts are needed to make the MMC more suitable for high power motor drives operating at low frequency range.

\section{Multiphase Motor Drives}

In the last three decades, multiphase motors were developed and are gaining popularity over the conventional threephase motors, due to their high-power density, fault-tolerant capability, and high efficiency ${ }^{(25)(110)(111)}$. Moreover, under fault conditions multiphase motors are more reliable, maintain self-starting ability with minimum effect on the output power level ${ }^{(25)}$. Some of the recent research topics on multiphase motor drives are: torque enhancement by injecting lower order harmonics into the stator currents ${ }^{(112)(113)}$, openended winding multiphase $\mathrm{IM}^{(41)}$ and matrix converter for five-phase $\mathrm{IM}^{(114)}$. These research works showed the importance and necessity for high-power multiphase motor drive applications. However, there are still no clear knowledge and certainty of the optimum number of phases required for a given application. It is obvious that increasing the number of phases increases the reliability of the drive system, but at the same time it also increases the complexity and cost of the related converter and control systems.

A comprehensive review of multiphase motor drives is presented by authors in works ${ }^{(33)(34)}$, where they presented the recent advances in the design, modeling and control of multiphase machines and discussed the open challenges and future research directions in this area. Even though the modeling of multiphase machines was extensively studied in the past century, some interesting and more accurate models are still being developed. These new models take into account the effect of the magnetic saturation in the machine that affects the main airgap flux density and produces coupling between different planes ${ }^{(33)}$.

Since modeling of any electric machine requires the knowledge of its electrical parameters, procedures for their identification are also becoming an interesting area of research ${ }^{(33)}$. In fact, motor parameters' identification (resistances and inductances) in conventional three-phase electrical machines is well-established, but their extension to the multiphase machines is currently limited. Therefore, more work is expected in the near future because only a few recent works have attempted to tackle this issue ${ }^{(33)}$.

\section{Challenges for High Power Motor Drives}

6.1 Long Cables Motors fed by PWM inverter with high $d v / d t$ pulses, via long cables, are subject to voltage spikes, which in turn induce severe nonlinear inter-coil and inter-turn voltage distributions in the motor windings. These voltage spike phenomena are caused by a combination of impedance mismatches, long motor cables, and inverter switching transients. If the cable is long enough, the voltage spikes at the receiving end (motor terminal connections) may reach twice the amplitude of the pulse voltage at the sending end (inverter terminals) ${ }^{(119)}$. This may damage motor windings' insulation and may lead to premature motor failures $^{(115)-(118)}$.

To reduce overvoltage and spikes at the motor terminals, several solutions were analyzed and proposed. A comprehensive research has been conducted on the modeling and analysis of these phenomena ${ }^{(120)-(126)}$. Passive RLC filters have been placed on the output terminal of the inverter to reduce the inverter $d v / d t^{(127)-(135)}$. Alternatively, these passive filters can be placed at the motor terminal side ${ }^{(136)(137)}$. Other types of passive filters and their placements are also possible ${ }^{(138)(139)}$. However, passive filters are bulky and increase power losses and costs. On the other hand, active filtering combined with new inverter topology (extra switches) has been proposed to reduce the overvoltage ${ }^{(140)}$. An active power filter with conventional inverter has been proposed in ${ }^{(141)}$. Also, a modified PWM switching pattern for a conventional three phase inverter was introduced in ${ }^{(142)(143)}$. An open-end winding electrical motor fed by two inverters of the same type and size has been also proposed ${ }^{(144)}$. An additional RC filter and PWM pulses dwell time control system are used to reduce the peak of the overvoltage. The proposed approach is independent of cable parameters and their variations. A good review of 
mitigation methods for overvoltage in long-cable-fed PWM AC drives can be found in ${ }^{(145)}$.

\subsection{Common Mode Voltage}

An inherent drawback of conventional two-level PWM inverter drive systems, is the generation of significant common-mode voltages (CMVs) with high frequency ${ }^{(146)(147)}$. Ground leakage and bearing currents along with conducted and radiated electromagnetic interference (EMI), are direct causes of the CMVs ${ }^{(148)-(150)}$. These common mode related problems will intensify with the availability of new fast switching devices that work at high speed and high frequency ${ }^{(151)-(154)}$. The CMV in PWM inverter-based motor drives is not a new issue ${ }^{(149)}$. Many practical industrial solutions were developed to mitigate the effects of CMVs in AC drive systems. Common-mode (CM) chokes were used to suppress the ground leakage current ${ }^{(155)-(157)}$, grounding brush or insulated bearings are commonly used to eliminate the bearing current ${ }^{(148)}, \mathrm{CM}$ filters are used to suppress the conducted CM EMI ${ }^{(158)(159)}$, while the use of shield cables reduce the radiated EMI. As they are dealing with CMVs effects and not the CMVs source, these techniques can only mitigate one particular effect at a time. More recently, some techniques were proposed to suppress the CMV itself using active filters ${ }^{(160)(161)}$. However, active filters are somewhat difficult to implement due to their highbandwidth and the need of an external voltage source. Authors in ${ }^{(162)(163)}$ reduced the CMV using modulation strategies that avoid zero switching states. Although, these PWM techniques are effective in reducing CM currents, they make the control more complex, increase the current harmonics, and cannot reduce the high-frequency EMI.

On the other hand, an effective way to cancel CMV is to use multilevel inverter topologies ${ }^{(164)(165)}$. Authors in ${ }^{(166)-(169)}$, proposed some inverter topologies for CMV cancellation Dual conventional two level inverters were used to cancel each other CMVs and drive the motor ${ }^{(167)(168)}$. However, this topology uses twice the number of switching devices and requires a good synchronization between the inverters. A costeffective and minimum-size topology using common-mode voltage cancellation in PWM motor drives with balanced inverter topology was proposed in ${ }^{(170)}$. The proposed balanced voltage source inverter (VSI) topology uses 3 switching devices in series per phase-leg. It eliminates the CMVs and their related problems in electric drives.

6.3 Torsional Vibrations (Long Shaft) In many applications, the load is coupled to the driving motor with a long shaft that is characterized by a small elasticity that may get magnified and cause torsional vibration effect on the load speed. This vibration is not only undesirable but can be often a source of system instability, and can result in coupling failure, shaft and gears damage. This in turn may cause undesired plant shutdowns ${ }^{(171)-(173)}$. Interactions between the electrical and mechanical sides of the drive system are the main source of magnification of torsional vibration excitations ${ }^{(174)(175)}$. Due to the DC link voltage fluctuation in VSI, the pulsating air-gap torque spectrum is composed of harmonics and inter-harmonics. Critical operation points, where the rotational speed of the motor causes harmonics and interharmonics coincident with one of the shaft torsional natural frequencies, can cause resonance and lead to system failure $^{(174)(175)}$. Beside the conventional losses, a recent study shows that additional losses are introduced in the electric motors under torsional vibration ${ }^{(184)}$.

To mitigate the torsional vibrations, several control strategies were proposed ${ }^{(176)(183)}$. These are based on: torque ripple suppression method with multilevel inverter and feedforward dead-time compensation ${ }^{(176)(177)}$, the fast and slow disturbance observers ${ }^{(178)}$, optimization techniques ${ }^{(179)}$, state-space controller $^{(180)(181)}$, Model Following Control (MFC) and Simulator Following Control (SFC) ${ }^{(182)}$, and Kalman filter ${ }^{(183)}$. The research on this issue will nurture as new drives are aiming for better bandwidth and therefore torsional vibrations will magnify.

6.4 Low-Voltage-Ride-Through (LVRT) to GridVoltage Sags Electric drives often trip during voltage sags, thus interrupting production and resulting in considerable financial losses. There are various types of electric drives, on the market, with different reactions to voltage sags. Therefore, by designing drives capable of riding through grid voltage sags with certain magnitude and duration, processes' downtime can be significantly reduced ${ }^{(185)}$. In order to prevent tripping due to voltage sags, various techniques have been proposed ${ }^{(186)(187)}$. These are mainly aimed at maintaining the DC-link voltage at a desirable level. This can be done based on:

1) Using compensation at the distribution level based on Dynamic Voltage Restorer (DVR) or STATCOM ${ }^{(188)}$, and

2) Modifying of drive topology using an extra boost converter between the rectifier and the DC-link capacitor $^{(189)(192)}$.

As the above techniques tend to be bulky and costly, another approach was proposed, which allows the DC-link voltage to vary, but a better inverter control technique is used ${ }^{(192)}$. However, if the process is sensitive to drops in torque and speed, it is better to proceed to controlled shutdown in order to minimize the damages, and have the process ready for starting when the voltage sag disappears ${ }^{(192)}$. Recently developed systems are based on energy storage using supercapacitor systems which can maintain the DC-bus voltage at the required level during the voltage sag ${ }^{(193)}$. Ride through time, voltage sags level, and load level are the main factors affecting the selection of the ride-through technique to be used for a given application.

6.5 Reliability and Availability Reliability and availability are key factors for the industry choices of high power motor drive, as it determines the lower downtime of their plants. Therefore, users of drive systems place reliability and availability on top of their wish list. The reliability is a measure of how long the drive system performs its envisioned function, while the availability is the time percentage during which the equipment is in the state of normal operation. However, the definitions of reliability and availability, or better the calculation of reliability and availability, are difficult to be directly converted into exact technical requirements.

The Mean Time Between Failures (MTBF) is normally used to calculate the reliability. ${ }^{(194)}$ gives the parameters for calculating MTBF, and clarification of these calculations is given in ${ }^{(195)}$. In this paper, we will highlight some technical guidelines about reliability ${ }^{(196)}$.

For inverter-driven motors, the use of simple topology with 
minimum number of switching devices is crucial for achieving high system reliability. The use of reliable switching devices, such as IEGT and GCT, will further enhance the reliability. Few proven inverter topologies such as 3-level NPC are becoming a standard for the industry. Especially the simple star-connected 5-level NPC inverter is appropriate for use with MV and HP motor drive ${ }^{(196)}$. Selection of a suitable control technique that eliminates low order harmonics and realizes smooth operation, also contributes to the increase of the overall drive system reliability. A proper testing at the manufacturing stage at various operating conditions is crucial for reliable operation in the real plant ${ }^{(196)}$.

The simplicity of the used grid side converters, such as diode rectifiers, will contribute to the overall reliability and availability of the drive system. As a general concept, simpler drives are normally more reliable and available than the complex ones ${ }^{(196)}$.

\section{Conclusion}

This paper surveyed and highlighted recent developments in HP and MV drives. This area in particular has recently experienced a considerable progress. A detailed overview of the current state-of-the-art in MV drives and their challenges, were described. Numerous interesting MV drives topologies, realizing the power up to $120 \mathrm{MW}$, were proposed. A highlight of the most prevalent topologies with a discussion of their features was presented.

New progress in power semiconductor devices will be the key element to achieving MV drives up to end-users' expectations such as simplicity, greater functionality, and better reliability. The number of researches published in this area is tremendous. The authors tried to refer to all important published works, and apologize to all authors whose important work may have been overlooked.

\section{References}

( 1 ) S. Rizzo and N. Zargari: "Medium voltage drives: what does the future hold?", The 4th International Power Electronics and Motion Control Conference, IPEMC 2004, Xi' an, 2004, Vol.1, pp.82-89 (2004)

( 2 ) H. Hosoda and S. Peak: "Multi-level converters for large capacity motor drive", The 2010 International Power Electronics Conference - ECCE ASIA-, Sapporo, pp.516-522 (2010)

( 3 ) S. Tadakuma: "Present status and future trends of electrical drives", IEEE, IPEC'95, pp.29-34 (1995)

( 4 ) S. Tadakuma and M. Ehara: "Historical and predicted trends of industrial AC drives", IEEE, IECON'93, pp.655-661 (1993)

( 5 ) W. Leonhard: "Control of Electrical Drives", Springer-Verglas (1985)

( 6 ) B.K. Bose: "Power Electronics and AC Drives", Englewood, NJ, PrenticeHal (1986)

( 7 ) M. Alhamadi, L. Ben-Brahim, and S. Tadakuma: "Industrial AC motor drives -Status of technology", International Power Electronics Conference, IPECTokyo (2000)

( 8 ) V.R. Stefanovic: "Industrial AC drives Status of Technology", EPE Journal, Vol.2, No.1, pp.7-24 (1992)

( 9 ) B.K. Bose: "Recent advances and trends in power electronics and drives", IEEE Power \& Industrial Electronics Conference (1998)

(10) L. Ben-Brahim, T. Yoshino, H. Abu-Rub, M. Malinowski, and K. Al-Haddad: "High-Power Drive Systems for Industrial Applications: Practical Examples", Power Electronics for Renewable Energy Systems Transportation and Industrial Applications, Chichester, UK, John Wiley \& Sons, Ltd. (2014)

(11) R. Dabbousi, D. Savinovic, and Y. Anundsson: "A Comparison Between Induction \& Synchronous Motors For Applications In The Oil \& Gas Industry", Petrolium and Chemical Industry Technical Conference, 2008 PCIC 2008,
22-25 (2008)

(12) R.P. Jastrzebski, P. Jaatinen, H. Sugimoto, O. Pyrhonen, and A. Chiba: "Design of a bearingless $100 \mathrm{~kW}$ electric motor for high-speed applications", in Proc. IEEE 18th International Conference on Electrical Machines and Systems (ICEMS2015), pp.2008-2014 (2015)

(13) Y. Fu, M. Takemoto, S. Ogasawara, and K. Orikawa: "Investigation of a high speed and high power density bearingless motor with neodymium bonded magnet", 2017 IEEE International Electric Machines and Drives Conference (IEMDC), Miami, FL, pp.1-8 (2017)

(14) R. Dabbousi, H. Balfaqih, Y. Anundsson, and D. Savinovic: "A comparison of totally enclosed motor coolers commonly used in the COG industry", Petroleum and Chemical Industry Conference, 2008 PCIC 2008 (2008)

(15) E.E. Ward and H. Harer: "Preliminary investigation of an inverter-fed 5-phase induction motor", Proc. IEE., Vol.116, No.6, pp.980-984 (1969)

(16) E. Levi: "Multiphase Electric Machines for Variable-Speed Applications", IEEE Transactions on Industrial Electronics, Vol.55, No.5, pp.1893-1909 (2008)

(17) M.A. Abbas, R. Christen, and T.M. Jahns: "Six-phase voltage source inverter driven induction motor", IEEE Trans. Ind. Appl., Vol.IA-20, No.5, pp.12511259 (1984)

(18) K.N. Pavithran, R. Parimelalagan, and M.R. Krishnamurthy: "Studies on inverter-fed five-phase induction motor drive", IEEE Trans. Power Electron., Vol.3, No.2, pp.224-235 (1988)

(19) E. Andrese and K. Bieniek: "6-phase induction motors for current-source inverter drives", in Conf. Rec. IEEE IAS Annu. Meeting, Philadelphia, PA, pp.607-618 (1981)

(20) K. Gopakumar, S. Sathiakumar, S.K. Biswas, and J. Vithayathil: "Modified current source inverter fed induction motor drive with reduced torque pulsations", Proc. Inst. Electr. Eng., Vol.131, No.4, pt.B, pp.159-164 (1984)

(21) J. Dente and F. Labrique: "Induction motor-current source inverter systems with phase number greater than 3", in Proc. EPE, Brussels, Belgium, pp.3.143-3.147 (1985)

(22) W. Cao, B.C. Mecrow, G.J. Atkinson, J.W. Bennett, and D.J. Atkinson "Overview of electric motor technologies used for More Electric Aircraft (MEA)", IEEE Trans. Ind. Electron., Vol.59, No.9, pp.3523-3531 (2012)

(23) J. Liu, L. Huang, H. Yu, C. Wen, and W. Zhong: "Study on the characteristics of a novel six-phase fault-torrent linear permanent magnet machine for linear oil pumping", IEEE Trans. Appl. Supercond., Vol.24, No.3, Art. ID. 5000305 (2014)

(24) J. Wang, R. Qu, and Y. Liu: "Comparison study of superconducting generators with multiphase armature windings for large-scale direct-drive wind turbine", IEEE Trans. Appl. Supercond., Vol.23, No.3, Art. ID. 5201005 (2013)

(25) E. Levi: "Multiphase electric machines for variable-speed applications", IEEE Trans. Ind. Electron., Vol.55, No.5, pp.1893-1909 (2008)

(26) A. Abdelkhalik, M. Masoud, and W. Barry: "Eleven-phase induction machine: Steady-state analysis and performance evaluation with harmonic injection", IET Elect. Power Appl., Vol.4, No.8, pp.670-685 (2010)

(27) L.A. Pereira, C.C. Scharlau, L.F.A. Pereira, and S. Haffner: "Influence of saturation on the airgap induction waveform of five-phase induction machines", IEEE Trans. Energy Convers., Vol.27, No.1, pp. 29-41 (2012)

(28) A.S. Abdel-Khalik and S. Ahmed: "Performance evaluation of a five phase modular winding induction machine", IEEE Trans. Ind. Electron., Vol.59, No.6, pp.2654-2669 (2012)

(29) P. Zheng, F. Wu, Y. Lei, Y. Sui, and B. Yu: "Investigation of a novel 24-slot/14-pole six-phase fault-tolerant modular permanent-magnet in-wheel motor for electric vehicles", Energies, Vol.6, No.10, pp.4980-5002 (2013)

(30) Y. Sui, et al.: "Research on a 20-slot/22-pole five-phase fault-tolerant PMSM used for four-wheel-drive electric vehicles", Energies, Vol.7, No.3, pp.12651287 (2014)

(31) A. Boglietti, et al.: "Electrical machine topologies: Hottest topics in the electrical machine research community”, IEEE Ind. Electron. Mag., Vol.8, No.2, pp.18-30 (2014)

(32) J. Wang, R. Qu, Y. Liu, and J. Li: "Study of multiphase superconducting wind generators with fractional-slot concentrated windings", IEEE Trans. Appl. Supercond., Vol.24, No.3, Art. ID. 5202106 (2014)

(33) F. Barrero and M.J. Duran: "Recent Advances in the Design, Modeling, and Control of Multiphase Machines-Part I", IEEE Transactions on Industrial Electronics, Vol.63, No.1, pp.449-458 (2016)

(34) M.J. Duran and F. Barrero: "Recent Advances in the Design, Modeling, and Control of Multiphase Machines-Part II", IEEE Transactions on Industrial Electronics, Vol.63, No.1, pp.459-468 (2016)

(35) G.K. Singh: "Multi-phase induction machine drive research—a survey", Electr. Power Syst. Res., Vol.61, pp.139-147 (2002)

(36) M. Jones and E. Levi: "A literature survey of state-of-the-art in multiphase AC drives", Proc. Universities Power Engineering Conference UPEC, Stafford, UK, pp.505-510 (2002) 
(37) E. Levi: "Recent Developments in High Performance Variable-Speed Multiphase Induction Motor Drives", Sixth International Symposium Nikola Tesla, Belgrade, Serbia (2006)

(38) T. Yoshino: "History and trends of converter technology for DC and AC transmission in Japan", 2014 International Power Electronics Conference (IPEC-Hiroshima 2014 - ECCE ASIA), Hiroshima, pp.3834-3841 (2014)

(39) M. Ruff, et al.: "SiC Divices: Physics and Numerical Simulation", IEEE Transactions on Electron Devices, Vol.41 (1994)

(40) C.M. Johnson: "Comparison of silicon and silicon carbide semiconductors for a $10 \mathrm{kV}$ switching application”, IEEE 35tg Annual Power Electronics Specialists Conference (IEEE Cat. No.04CH37551), Vol.1, p 572-8 (2004)

(41) A.I. Maswood, L. Ben-Brahim, and P. Harikrishnaraj: "An investigation into the efficiency of silicon carbide based power inverters", 2016 4th International Conference on the Development in the in Renewable Energy Technology (ICDRET), Dhaka, pp.1-6 (2016)

(42) T. Kimoto, et al.: "Progress and future challenges of SiC power devices and process technology”, 2017 IEEE International Electron Devices Meeting (IEDM), San Francisco, CA, pp.9.5.1-9.5.4 (2017)

(43) R.H. Baker and L.H. Bannister: "Electric Power Converter", U.S. Patent 3 867643 (1975)

(44) S. Miyazaki, R. Kurosawa, and L. Ben-Brahim: "Characteristics Improvement of a PWM Controlled Three Level GTO Inverter", National Convention record I.E.E. Japan (1993) (in Japanese)

(45) A. Nabae, I. Takahashi, and H. Akagi: "A New Neutral-point Clamped PWM inverter", IEEE Trans. Ind. Applicat., Vol.IA-17, pp.518-523 (1981)

(46) T.A. Meynard and H. Foch: "Multi-Level Conversion: High Voltage Choppers and Voltage-Source Inverters", Power Electronics Specialists Conference, 1992. PESC '92 Record., 23rd Annual IEEE, Toledo, Vol.1, pp.397403 (1992)

(47) T.A. Meynard: "Modeling of multilevel converters", IEEE Trans. Ind. Electron., Vol.44, No.3, pp.356-364 (1997)

(48) T.A. Meynard, H. Foch, P. Thomas, J. Courault, R. Jakob, and M. Nahrstaedt: "Multicell converters: basic concepts and industry applications", IEEE Trans. Ind. Electron., Vol.49, No.5, pp.955-964 (2002)

(49) P.W. Hammond: "A new approach to enhance power quality for medium voltage AC drives", IEEE Trans. IA, Vol.33, No.1, pp.202-208 (1997)

(50) P.W. Hammond: "Medium Voltage PWM Drive and Method", U.S. Patent 5 625545 (1977)

(51) F.Z. Peng and J.S. Lai: "Multilevel Cascade Voltage-source Inverter with Separate DC source", U.S. Patent 5642275 (1997)

(52) P.W. Hammond: "Four-quadrant AC-AC Drive and Method", U.S. Patent 6 166513 (2000)

(53) M.F. Aiello, P.W. Hammond, and M. Rastogi: "Modular Multi-level Adjustable Supply with Series Connected Active Inputs", U.S. Patent 6236580 (2001)

54) M.F. Aiello, P.W. Hammond, and M. Rastogi: "Modular Multi-Level Adjustable Supply with Parallel Connected Active Inputs", U.S. Patent 6301 130 (2001)

(55) A. Lesnicar and R. Marquardt: "An innovative modular multilevel converter topology suitable for a wide power range", 2003 IEEE Bologna Power Tech Conference Proceedings, Vol.3, p.6 (2003)

(56) L. Ben-Brahim, A. Gastli, M. Trabelsi, K.A. Ghazi, M. Houchati, and H. Abu-Rub: "Modular Multilevel Converter Circulating Current Reduction Using Model Predictive Control", IEEE Transactions on Industrial Electronics, Vol.63, No.6, pp.3857-3866 (2016)

57 ) R.W. Erickson and O.A. Al-Naseem: "A New Family of Matrix Converters", IEEE Industrial Electronics Society Annual Conference (IECON'01), 1515$1520(2001)$

(58) O.A. Al-Naseem: "Modeling and Space Vector Control of a Novel Multilevel Matrix Converter for Variable-Speed Wind Power Generators", Ph.D. Thesis, University of Colorado (2001)

(59) S. Angkititrakul and R.W. Erickson: "Control and Implementation of a New Modular Matrix Converter", IEEE Applied Power Electronic Conference, Vol.2, pp.813-819 (2004)

(60) L. Pei, Z. Jianlin, and L. Lijuan: "On topology and mathematical model of multilevel matrix converter", 2008 27th Chinese Control Conference, Kunming, pp.310-314 (2008)

61 ) R.H. Baker: "Bridge Converter Circuit", U.S. Patent 4270163 (1981)

(62) H. Liu, N. Choi, and G. Cho: "DSP based space vector PWM for threelevel inverter with DC-link voltage balancing”, IEEE IECON'91, pp.197-203 (1991)

(63) H.L. Liu and G.H. Cho: "Three-Level Space Vector PWM in Low Index Modulation Region Avoiding Narrow Pulse Problem", IEEE Transactions on Power Electronics, Vol.9, No.5 (1994)

(64) L. Li, D. Czarkowski, Y. Liu, and P. Pillay: "Multilevel Selective Harmonic Elimination PWM Technique in Series-Connected Voltage Convert- ers", IEEE Transactions on Industry Applications, Vol.36, No.1, pp.160-170 (2000)

(65) N.V. Nguyen, B.X. Nguyen, and H.H. Lee: "An Optimized Discontinuous PWM Method to Minimize Switching Loss for Multilevel Inverters", IEEE Trans. Industrial Electronics, Vol.58, No.9, pp.3958-3966 (2011)

(66) H. Khan, E.H. Miliani, and K.E.K. Drissi: "Discontinuous Random Space Vector Modulation for Electric Drives: A Digital Approach", IEEE Trans. Power Electronics, Vol.27, No.12, pp.4944-4951 (2012)

(67) P. Sun, C. Liu, and J.-S. Lai: "Three-Phase Dual-Buck Inverter with Unified Pulse width Modulation”, IEEE Trans. Power Electronics, Vol.27, No.3, pp.1159-1167 (2012)

(68) O. Ojo: "The generalized discontinuous PWM scheme for three-phase voltage source inverters", IEEE Trans. Industrial Electronics, Vol.51, No.6, pp.1280-1289 (2004)

(69) A.M. Hava, R.J. Kerkman, and T.A. Lipo: "A High-Performance Generalized Discontinuous PWM Algorithm”, IEEE Trans. Industry Applications, Vol.34, No.5, pp.1059-1071 (1998)

(70) H.J. Kim, H.D. Lee, and S.K. Sul: "A New PWM Strategy for CommonMode Voltage Reduction in Neutral-Point-Clamped Inverter-Fed AC Motor Drives", IEEE Transactions on Industry Applications, Vol.37, No.6, pp. $1840-1845$ (2001)

(71) C. Newton and M. Sumner: "Neutral Point Control for Multi- Level Inverters: theory, design and operational limitations", IEEE Ind. Applicat. Soc. Conf. Rec., pp.1336-1343 (1997)

(72) Y.H. Lee, B.S. Suh, and D.S. Hyun: "A Novel PWM Scheme for a ThreeLevel Voltage Source Inverter with GTO Thyristors", IEEE Transactions on Industry Applications, Vol.32, No.2 (1996)

(73) S. Tanaka, K. Miura, T. Watanabe, S. Tadakuma, and H. Ikeda: "Consideration on PWM control for Neutral-Point-Clamped inverter", Trans. IEE of Japan, Vol.112-D, No.6 (1992) (in Japanese)

(74) L. Ben-Brahim: "Improvement of a PWM Controlled NPC GTO Inverter for AC Motor Drives", ISIE99 Proceedings, Slovenia (1999)

(75) L. Ben-Brahim and S. Tadakuma: "A New PWM control for GTO minimum on-pulse compensation", Industry Applications Conference, IAS Annual Meeting, Vol.2, pp.1015-1022 (2001)

(76) L. Ben-Brahim and S. Tadakuma: "A Novel Multilevel Carrier-Based PWM Control Method for GTO Inverter in Low Index Modulation Region”, IEEE Transactions on Industry Applications, Vol.42, No.1 (2006)

(77) L. Ben-Brahim: "A Discontinuous PWM Method for Balancing the Neutral Point Voltage in Three-Level Inverter-Fed Variable Frequency Drives (VFDs)", IEEE Transactions on Energy Conversion, Vol.23, No.4, pp.10571063 (2008)

(78) J. Rodriguez, J.S. Lai, and F.Z. Peng: "Multilevel Inverters: Survey of Topologies, Controls, and Applications", IEEE Transactions on Industry Applications, Vol.49, No.4, pp.724-738 (2002)

(79) H. Akagi: "Multilevel Converters: Fundamental Circuits and Systems", The Proceedings of the IEEE, Vol.105, No.11, pp.2048-2065 (2017)

(80) J. Kolb, F. Kammerer, M. Gommeringer, and M. Braun: "Cascaded control system of the modular multilevel converter for feeding variable-speed drives", IEEE Trans. Power Electron., Vol.30, No.1, pp.349-357 (2015)

(81) K. Kaneko, T. Okamoto, and A. Goyal: "MV drive inverter development for higher capacity and higher reliability", 2016 IEEE International Conference on Power Electronics, Drives and Energy Systems (PEDES), Trivandrum, pp.1-5 (2016)

(82) F. Endrejat, R.A. Hanna, and J. Shultz: "Ensuring availability of a large adjustable-speed drive for process gas compressor application rated $11 \mathrm{kV}$ 15.5 MW (20 778 hp)", IEEE Trans. Ind. Appl., Vol.46, No.5, pp.1843- 1849 (2010)

(83) M. Abolhassani: "Modular multipulse rectifier transformers in symmetrical cascaded H-bridge medium voltage drives", IEEE Trans. Power Electron., Vol.27, No.2, pp.698-705 (2012)

(84) A.J. Korn, M. Winkelnkemper, and P. Steimer: "Low output frequency operation of the modular multilevel converter", in Proc. IEEE ECCE, pp.39933997 (2010)

(85) S. Debnath, J. Qin, and M. Saeedifard: "Control and stability analysis of modular multilevel converter under low-frequency operation", IEEE Trans. Ind. Electron., Vol.62, No.9, pp.5329-5339 (2015)

(86) K. Wang, Y. Li, Z. Zheng, and L. Xu: "Voltage balancing and fluctuation suppression methods of floating capacitors in a new modular multilevel converter”, IEEE Trans. Ind. Electron., Vol.60, No.5, pp.1943-1954 (2013)

(87) J.J. Jung, H.J. Lee, and S.-K. Sul: "Control strategy for improved dynamic performance of variable-speed drives with modular multilevel converter", IEEE J. Emerging Sel. Topics Power Electron., Vol.3, No.2, pp.371-380 (2015)

(88) M. Hagiwara, I. Hasegawa, and H. Akagi: "Start-up and low-speed operation of an electric motor driven by a modular multilevel cascade inverter", IEEE 
Trans. Ind. Appl., Vol.49, No.4, pp.1556-1565 (2013)

(89) D. Busse, J. Erdman, R. Kerkman, D. Schlegel, and G. Skibinski: "System electrical parameters and their effects on bearing currents", IEEE Trans. Ind. Appl., Vol.33, No.2, pp.577-584 (1997)

(90) A. Antonopoulos, L. Angquist, L. Harnefors, and H.P. Nee: "Optimal selection of the average capacitor voltage for variable-speed drives with modular multilevel converters", IEEE Trans. Power Electron., Vol.30, No.1, pp.227234 (2015)

(91) A. Antonopoulos, L. Angquist, S. Norrga, K. Ilves, L. Harnefors, and H.-P. Nee: "Modular multilevel converter AC motor drives with constant torque from zero to nominal speed", IEEE Trans. Ind. Appl., Vol.50, No.3, pp.1982$1993(2014)$

(92) S. Du, B. Wu, K. Tian, N.R. Zargari, and Z. Cheng: "An Active CrossConnected Modular Multilevel Converter (AC-MMC) for a Medium-Voltage Motor Drive", IEEE Transactions on Industrial electronics, Vol.63, No.8 (2016)

(93) J.P. Lavieville, P. Carrere, and T. Meynard: "Electronic Circuit for Converting Electrical Energy and a Power Supply Installation Making Use Thereof", U.S. Patent 5668711 (1997)

(94) T. Meynard, J.-P. Lavieville, P. Carrere, J. Gonzalez, and O. Bethoux: "Electronic Circuit for Converting Electrical Energy", U.S. Patent 5706188 (1998)

(95) E. Cengelci, S.U. Sulistijo, B.O. Woom, P. Enjeti, R. Teodorescu, and F. Blaabjerg: "A New Medium Voltage PWM Inverter Topology for Adjustable Speed Drives", in Conf. Rec. IEEE-IAS Annu. Meeting, St. Louis, MO, pp.1416-1423 (1998)

(96) J.S. Lai and F.Z. Peng: "Multilevel Converters-A new Breed of Power Converters", IEEE Trans. Ind. Applicat., Vol.32, pp.509-517 (1996)

(97) L.M. Tolbert, F.Z. Peng, and T. Habetler: "Multilevel Converters for Large Electric drives", IEEE Trans. Ind. Applicat., Vol.35, pp.36-44 (1999)

(98) M.F. Escalante, J.C. Vannier, and A. Arzande: "Flying Capacitor Multilevel Inverters and DTC Motor Drive Applications", IEEE Transactions on Industry Electronics, Vol.49, No.4, pp.809-815 (2002)

(99) L.M. Tolbert, F.Z. Peng, and T.G. Habetler: "Multilevel Inverters for Electric Vehicle Applications", IEEE Workshop on Power Electronics in Transportation, Dearborn, Michigan, pp.1424-1431.31-47 (1998)

(100) L.M. Tolbert, F.Z. Peng, T. Cunnyngham, and J.N. Chiasson: "Charge Balance Control Schemes for Multilevel Converter in Hybrid Electric Vehicles", IEEE Transactions on Industrial Electronics, Vol.49, No.5, pp.1058-1065 (2002)

(101) M.D. Manjrekar and T.A. Lipo: "A Hybrid Multilevel Inverter Topology for Drive Applications”, IEEE Applied Power Electronics Conference, pp.523529 (1998)

(102) K. Corzine and Y. Familiant: "A New Cascaded Multilevel H-Bridge Drive", IEEE Transactions on Power Electronics, Vol.17, No.1, pp.125-131 (2002)

(103) W.A. Hill and C.D. Harbourt: "Performance of medium voltage multilevel converters", in Conf. Rec. IEEE-IAS Annu. Meeting, Phoenix, AZ, pp.11861192 (1999)

(104) L.M. Tolbert and F.Z. Peng: "Multilevel Converters as a Utility Interface for Renewable Energy Systems", in Proceedings of 2000 IEEE Power Engineering Society Summer Meeting, pp.1271-1274 (2000)

(105) F.Z. Peng, J.W. McKeever, and D.J. Adams: "Cascade Multilevel Inverters for Utility Applications", Proceedings of 23rd International Conference on Industrial Electronics, Control, and Instrumentation, pp.437-442 (1997)

(106) G. Joos, X. Huang, and B.T. Ooi: "Direct-Coupled Multilevel Cascaded Series VAR Compensators", Conference Record - IEEE Industry Applications Society 32nd Annual Meeting, pp.1608-1615 (1997)

(107) R.W. Menzies and Y. Zhuang: "Advanced Static Compensation Using a Multilevel GTO Thyristor Inverter", IEEE Transactions on Power Delivery, Vol.10, No.2, pp.732-738 (1995)

(108) M.D. Manjrekar and T.A. Lipo: "A Generalized Structure of Multilevel Power Converter", IEEE Conference on Power Electronics, Drives, and Energy Systems, Australia, pp.62-67 (1998)

(109) C. Hochgraf, R. Lasseter, D. Divan, and T.A. Lipo: "Comparison of Multilevel Inverters for Static Var Compensation", Conference Record - IEEE Industry Applications Society 29th Annual Meeting, pp.921-928 (1994)

(110) T.M. Jahns: "Improved reliability in solid-state AC drives by means of multiple independent phase drive units", IEEE Trans. Ind. Appl., Vol.IA-16, No.3, pp.321-331 (1980)

(111) E. Levi, R. Bojoi, F. Profumo, H.A. Toliyat, and S. Williamson: "Multiphase induction motor drives-A technology status review", IET Elect. Power Appl., Vol.1, No.4, pp.489-516 (2007)

(112) M. Mengoni, L. Zarri, A. Tani, L. Parsa, G. Serra, and D. Casadei: "High torque-density control of multiphase induction motor drives operating over a wide speed range", IEEE Trans. Ind. Electron., Vol.62, No.2, pp.814-825 (2015)
(113) B.P. Reddy and S. Keerthipati: "A Multilevel Inverter Configuration for an Open-End-Winding Pole-Phase-Modulated-Multiphase Induction Motor Drive Using Dual Inverter Principle", IEEE Transactions on Industrial Electronics, Vol.65, No.4, pp.3035-3044 (2018)

(114) K. Rahman, A. Iqbal, N. Al-Emadi, and L. Ben-Brahim: "Common mode voltage reduction in a three-to-five phase matrix converter fed induction motor drive", in IET Power Electronics, Vol.10, No.7, pp.817-825 (2017)

(115) M. Young: "The Technical Writer's Handbook", Mill Valley, CA, USA: University Science (1989)

(116) A. von Jouanne, D.A. Rendusara, P.N. Enjeti, and J.W. Gray: "Filtering techniques to minimize the effect of long motor leads on PWM inverter-fed AC motor drive systems", IEEE Trans. Ind. Appl., Vol.32, No.4, pp.919-926 (1996)

(117) L. Wang, C. Ho, F. Canales, and J. Jatskevich: "High-frequency modeling of the long-cable-fed induction motor drive system using TLM approach for predicting overvoltage transients", IEEE Trans. Power Electron., Vol.25, No.10, pp.2653-2664 (2010)

(118) B. Mirafzal, G.L. Skibinski, and R.M. Tallam: "A failure mode for PWM inverter-fed AC motors due to the anti-resonance phenomenon", IEEE Trans. Ind. Appl., Vol.45, No.5, pp.1697-1705 (2009)

(119) E. Persson: "Transient effects in application of PWM inverters to induction motors", IEEE Trans. Ind. Appl., Vol.28, No.5, pp.1095-1101 (1992)

(120) R. Kerkman, D. Leggate, and G. Skibinski: "Interaction of Drive Modulation and Cable Parameters on AC Motor Transient", IEEE Trans. Ind. Appl., Vol.33, No.3, pp.722-731 (1997)

(121) M. Berth, L. Kung, and E.F.D.E. Limbeek: "Switching overvoltages in motor circuits", IEEE Trans. Ind. Appl., Vol.37, No.6, pp.1582-1589 (2013)

(122) R.J. Kerkman, D. Leggate, D. Schlegel, and G. Skibiski: "PWM Inverters and Their Influence on Motor Over-Voltage", IEEE APEC Conference Proceeding, Vol.1, pp.103-113 (1997)

(123) A.F. Moreira, T.A. Lipo, G. Venkataramanan, and S. Bernet: "High frequency modeling for cable and induction motor overvoltage studies in long cable drives", IEEE Trans. Ind. Appl., Vol.38, No.5, pp.1297-1306 (2002)

(124) Takahashi, M. Termeyer, T. Lowery, and H. Tsai: "Motor Lead Length issues for IGBT drives", IEEE Pulp and Paper Industry Technical Conference, pp.21-27 (1995)

(125) S. Van Haute, A. Malfait, R. Reekmans, and R. Belmans: "Losses, Audible Noise, and Overvoltage in Induction Motor Drives", IEEE PESC, Vol.1, pp.585-592 (1995)

(126) L. Gubbala, A. von Juanne, P. Enjeti, C. Singh, and H. Toliyat: "Voltage Distribution in the Windings of an AC motor subjected to high dv/dt PWM voltages", IEEE PESC Conference Proceeding, Vol.1, pp.579-585 (1995)

(127) A. von Juanne, D. Rendusara, P. Enjeti, and W. Gray: "Filtering techniques to minimize the effect of long motor leads on PWM inverter fed AC motor drive systems", IEEE Trans. Ind. Appl., Vol.32, No.4, pp.919-926 (1996)

(128) L. Palma and P. Enjeti: "An inverter output filter to mitigate dv/dt effects in PWM drive systems", IEEE APEC Conference Proceeding, Vol.1, pp.550556 (2002)

(129) T. Habetler, R. Naik, and T. Nondahl: "Design and implementation of an inverter output LC filter used for dv/dt reduction", IEEE Trans. Power Electron., Vol.17, No.3, pp.327-331 (2002)

(130) D. Rendusara and P. Enjeti: "New inverter output filter configuration reduces common mode and differential mode dv/dt at the motor terminals in PWM drive systems", in Proc. IEEE PESC, Vol.2, pp.1269-1275 (1997)

(131) N. Hanigovszki, J. Poulsen, and F. Blaabjerg: "A novel output filter topology to reduce motor overvoltage", IEEE Trans. Ind. Appl., Vol.40, No.3, pp.845852 (2004)

(132) H. Akagi and I. Matsumura: "Overvoltage Mitigation of Inverter-Driven Motors with Long Cables of Different Lengths", IEEE Trans. Ind. Appl., Vol.47, No.4, pp.1741-1748 (2011)

(133) A. Moreira, P. Santos, T. Lipo, and G. Venkataramanan: "Filter networks for long cable drives and their influence on motor voltage distribution and common-mode current", IEEE Trans. Ind. Electron., Vol.52, No.2, pp.515$522(2005)$

(134) R.M. Tallaman, G. Skibinski; T.A. Shudarek, and R.A. Lukaszewski "Integrated differential-mode and common-mode filter to mitigate the effects of long motor leads on ac drives", IEEE Trans. Ind. Appl., Vol.47, No.5, pp.2075-2083 (2011)

(135) N. Aoki, K. Sato, and A. Nabae: "Damping Circuit to suppress motor terminal overvoltage and ringing in PWM inverter-fed ac motor drive systems with long motor leads", IEEE Ind. Appl., Vol.35, No.5, pp.1014-1020 (1999)

(136) F. Castelli-Dezza, M.M. Maglio, G. Marchegiani, D.F. Ortega, and D. Rosati: "Reduction of motor overvoltage fed by PWM AC drives using a Universal model”, XIX In Proc. Conf. on Electrical Machines- ICEM, pp.1-6, Rome (2010)

(137) G.L. Skibinski: "Design Methodology of a cable terminator to reduce 
reflected voltage on ac motors", IEEE in Proc. Conf., Vol.1, pp.153-161 (1996)

(138) K.K.F. Yuen and H. Shu Hung Chung: "A Low-Loss RL-Plus-C Filter for Overvoltage Suppression in Inverter-Fed Drive System with long motor cable", IEEE Trans. on Power Electr., Vol.30, No.4, pp.2167-2181 (2015)

(139) Y. Jiang, W. Wu, Y. He, H.S.H. Chung, and F. Blaabjerg: "New Passive Filter Design Method for Overvoltage Suppression and Bearing Currents Mitigation in a Long Cable Based PWM Inverter-Fed Motor Drive System", IEEE Transactions on Power Electronics, Vol.32, No.10, pp.7882-7893 (2017)

(140) S. Lee and K. Nam: "An overvoltage suppression scheme for AC motor drives using a half DC-link voltage level at each PWM transition", IEEE Trans. Ind. Electron., Vol.49, No.3, pp.549-557 (2002)

(141) K.K.F. Yuen, H.S.H. Chung, and V.S.P. Cheung: "An Active Low-Loss Motor Terminal Filter for Overvoltage Suppression and Common Mode Current Reduction", IEEE Trans. Ind. Electron., Vol.27, No.7, pp.3158-3172 (2012)

(142) S.C. Lee: "Perfect wave oscillation suppression with reflection coefficients adaptation in PWM motor drives with long feeding cables", IEE. Proc. Electr. Power Appl., Vol.153, No.3, pp.467-472 (2006)

(143) R.M. Tallaman and D. Leggate: "Control of a PWM voltage-source inverter in the pulse-dropping region to reduce reflected-wave motor overvoltage", IEEE Trans. Ind. Appl., Vol.49, No.2, pp.873-879 (2013)

(144) S. Foti, et al.: "Overvoltage mitigation in open-end winding AC motor drives”, 2015 International Conference on Renewable Energy Research and Applications (ICRERA), Palermo, pp.238-245 (2015)

(145) J. He, G.Y. Sizow, P. Zhang, and N.A.O. Demerdash: "A review of mitigation methods for overvoltage in long-cable-fed PWM AC drives", in Proc. Conf. Rec. Energy Convers. Congr. Expo., pp.2160-2166 (2011)

(146) E. Zhong and T.A. Lipo: "Improvements in EMC performance of inverter fed motor drives", IEEE Trans. Ind. Appl., Vol.31, No.6, pp.1247-1256 (1995)

(147) G. Skibinski, R. Kerkman, and D. Schlegel: "EMI emissions of modern PWM AC drives", IEEE Ind. Appl. Mag., Vol.5, No.6, pp.47-80 (1999)

(148) M. Erdman, R.J. Kerkman, D.W. Schlegel, and G.L. Skibinski: "Effect of PWM inverters on AC motor bearing currents and shaft voltages", IEEE Trans. Ind. Appl., Vol.32, No.2, pp.250-259 (1996)

(149) S. Chen, T.A. Lipo, and D. Fitzgerald: "Source of induction motor bearing currents caused by PWM inverters", IEEE Trans. Energy Convers., Vol.11, No.1, pp.25-32 (1996)

(150) S. Ogasawara, H. Ayano, and H. Akagi: "Measurement and reduction of EMI radiated by a PWM inverter-fed AC motor drive system", IEEE Trans. Ind. Appl., Vol.33, No.4, pp.1019-1026 (1997)

(151) N. Oswald, P. Anthony, N. McNeill, and B.H. Stark: "An experimental investigation of the tradeoff between switching losses and EMI generation with hard-switched all-Si, Si-SiC, and all-SiC device combinations", IEEE Trans. Power Electron., Vol.29, No.5, pp.2393-2407 (2014)

(152) X. Gong and J.A. Ferreira: "Comparison and reduction of conducted EMI in SiC JFET and Si IGBT-based motor drives", IEEE Trans. Power Electron., Vol.29, No.4, pp.1757-1767 (2014)

(153) D. Han, C. Morris, W. Lee, and B. Sarlioglu: "Determination of CM choke parameters for SiC MOSFET motor drive based on simple measurements and frequency domain modeling", in Proc. IEEE Appl. Power Electron. Conf. Expo., Long Beach, CA, USA, pp.2861-2867 (2016)

(154) H. Niu and R.D. Lorenz: "Sensing power MOSFET junction temperature using gate drive turn-on current transient properties", IEEE Trans. Ind. Appl., Vol.52, No.2, pp.1677-1687 (2015)

(155) A. Muetze and C.R. Sullivan: "Simplified design of common-mode chokes for reduction of motor ground currents in inverter drives", IEEE Trans. Ind. Appl., Vol.47, No.6, pp.2570-2577 (2011)

(156) M.L. Heldwein, L. Dalessandro, and J.W. Kolar: "The three-phase commonmode inductor: Modeling and design issues", IEEE Trans. Ind. Electron., Vol.58, No.8, pp.3264-3274 (2011)

(157) R. Wrobel, N. McNeill, and P.H. Mellor: "Performance analysis and thermal modeling of a high-energy-density prebiased inductor", IEEE Trans. Ind. Electron., Vol.57, No.1, pp.201-208 (2010)

(158) H. Akagi and T. Shimizu: "Attenuation of conducted EMI emissions from an inverter-driven motor", IEEE Trans. Power Electron., Vol.23, No.1, pp.282290 (2008)

(159) H. Akagi and T. Doumoto: "A passive EMI filter for preventing high frequency leakage current from flowing through the grounded inverter heat sink of an adjustable-speed motor drive system", IEEE Trans. Ind. Appl., Vol.41, No.5, pp.1215-1223 (2005)

(160) Y.C. Son and S.-K. Sul: "A new active common-mode EMI filter for PWM inverter”, IEEE Trans. Power Electron., Vol.18, No.6, pp.1309-1314 (2003)

(161) C. Zhu and T.H. Hubing: "An active cancellation circuit for reducing electrical noise from three-phase AC motor drivers", IEEE Trans. Electromagn. Compat., Vol.56, No.1, pp.60-66 (2014)

(162) R.M. Tallam, R.J. Kerkman, D. Leggate, and R.A. Lukaszewski:
"Common-mode voltage reduction PWM algorithm for AC Drives", IEEE Tran. Ind. Appl., Vol.46, No.5, pp.1959-1969 (2010)

(163) E. Un and A.M. Hava: "A near-state PWM method with reduced switching losses and reduced common-mode voltage for three-phase voltage source inverters", IEEE Trans. Ind. Appl., Vol.45, No.2, pp.782-793 (2009)

(164) F. Wang: "Motor shaft voltages and bearing currents and their reduction in multilevel medium-voltage PWM voltage-source-inverter drive applications", IEEE Trans. Ind. Appl., Vol.36, No.5, pp.1336-1341 (2000)

(165) J. Wang, Y. Li, and Y. Han: "Integrated modular motor drive design with GaN power FETs", IEEE Trans. Ind. Appl., Vol.51, No.4, pp.3198-3207 (2015)

(166) C.T. Morris, D. Han, and B. Sarlioglu: "Reduction of common mode voltage and conducted EMI through three phase inverter topology", IEEE Trans. Power Electron., No.99, p.1

(167) A. Julian, G. Oriti, and T. Lipo: "Elimination of common-mode voltage in three-phase sinusoidal power converters", IEEE Trans. Power Electron., Vol.14, No.5, pp.982-989 (1999)

(168) M. Baiju, K. Mohapatra, R. Kanchan, and K. Gopakumar: "A dual two level inverter scheme with common mode voltage elimination for an induction motor drive", IEEE Trans. Power Electron., Vol.19, No.3, pp.794-805 (2004)

(169) A. Von Jauanne and H. Zhang: "A dual-bridge inverter approach to eliminating common-mode voltages and bearing and leakage currents", IEEE Trans. Power Electron., Vol.14, No.1, pp.43-48 (1999)

(170) D. Han, C.T. Morris, and B. Sarlioglu: "Common-Mode Voltage Cancellation in PWM Motor Drives With Balanced Inverter Topology", IEEE Transactions on Industrial Electronics, Vol.64, No.4, pp.2683-26881 (2017)

(171) T. Holopain, J. Niiranen, P. Jörg, and D. Andreo: "Electric Motors and Drives in Torsional Vibration Analysis and Design", Proceedings of the 42nd Turbomachinery Symposium, Houston, Texas (2013)

(172) P. Jörg, A. Lenzi, and V. Depau: "Optimization of Transient Behavior of Complex Turbocompressor Shaft Lines", IEEE (IAS) Industry Applications Society Annual Meeting, pp.1-13 (2011)

(173) S. Del Puglia, S. Franciscis, S. Van de Moortel, P. Jörg, T. Hattenbach, D. Sgrò, L. Antonelli, and S. Falomi: "A Torsional Interaction Optimization in a LNG Train with Load Commutated Inverter", $8^{\text {th }}$ IFToMM International Conference on Rotor Dynamics 2010 Seoul, Korea (2010)

(174) M. Mauri, M. Rossi, and M. Bruha: "Generation of torsional excitation in a variable-speed-drive system”, 2016 International Symposium on Power Electronics, Electrical Drives, Automation and Motion (SPEEDAM), Anacapri, pp.516-521 (2016)

(175) M. Tsukakoshi, M. Al Mamun, K. Hashimura, H. Hosoda, J. Sakaguchi, and L. Ben-Brahim: "Novel Torque Ripple Minimization Control for $25 \mathrm{MW}$ Variable Speed Drive System Fed by Multilevel Voltage Source Inverter", 39th Turbomachinery Symposium, Houston, USA (2010)

(176) S. Shimmyo, K. Takeuchi, N. Takahashi, M. Matsushita, and K. Ohnishi: "Multi-level Motor Drives for Torque Ripple Suppression Taking Control Sensitivity into Account", IEEJ Journal Industry Applications, Vol.5, No.2, pp.69-77 (2016)

(177) S. Shimmyo, K. Yuki, and K. Ohnishi: "Torque Ripple Suppression Method with Multilevel Inverter and Feedforward Dead-Time Compensation", IEEJ J. Industry Applications, Vol.5, No.4, pp.360-369 (2016)

(178) Y. Hori: "Comparison of torsional vibration controls based on the fast and slow disturbance observers", IPEC'95, pp.440-446 (1995)

(179) L. Harnefors, S.E. Saarakkala, and M. Hinkkanen: "Speed control of electrical drives using classical control methods", IEEE Transactions on Industry Applications, Vol.49, No.2, pp.889-898 (2013)

(180) S.E. Saarakkala and M. Hinkkanen: "State-space speed control of two mass mechanical systems: Analytical tuning and experimental evaluation”, IEEE Transactions on Industry Applications, Vol.50, No.5, pp.3428-3437 (2014)

(181) K. Szabat and T. Orlowska-K owalska: "Vibration suppression in a two mass drive system using PI speed controller and additional feedbacks - Comparative study", IEEE Transactions on Industrial Electronics, Vol.54, No.2, pp.1193-1206 (2007)

(182) T. Hasegawa, et al.: "A microcomputer-based motor drive system with simulator following control”, IEEE IECON'86, Vol.1, p.41 (1986)

(183) J.K. Ji and S.K. Sul: "Kalman filter and LQ based speed controller for torsional vibration suppression in a 2-mass motor drive system", IEEE Transactions on Industrial Electronics, Vol.42, No.6, pp.564-571 (1995)

(184) A. Arkkio, S. Cederström, H.A.A. Awan, S.E. Saarakkala, and T.P Holopainen: "Additional Losses of Electrical Machines Under Torsional Vibration”, IEEE Transactions on Energy Conversion, Vol.33, No.1, pp.245251 (2018)

(185) A. Van Zyl, R. Spee, A. Faveluke, and S. Bhowmik: "Voltage sag ridethrough for adjustable-speed drives with active rectifiers", IEEE Transactions on Industry Applications, Vol.34, No.6, pp.1270-1277 (1998)

(186) F. Beiser: "Voltage dip research and investigation", Elektron, p.21 (1994)

(187) R.A. Epperley, F.L. Hoadley, and R.W. Piefer: "Considerations when 
applying ASD's in continuous processes", IEEE Trans. Ind. Applicat., Vol.33, pp.389-396 (1997)

(188) D. Almeida: "Technical and economical considerations in the application of variable-speed drives with electric motor systems", IEEE Transaction on Industry Applications, Vol 41, No.1 (2005)

(189) J.L. Duran-Gomez and P. Enjeti: "A low cost approach to improve the performance of an adjustable speed drive (ASD) under voltage sags and short term interruptions", in Proc. Applied Power Electronics Conference and Exposion, 13th Annual Meeting, Vol.2, pp.587-591 (1998)

(190) J.L. Duran-Gomez, P.N. Enjeti, and B.O. Woo: "Effect of voltage sags on adjustable speed drives - a critical evaluation and an approach to improve its performance", IEEE Transactions on Industry Applications, Vol.35, No.6, pp.1440-1449 (1999)

(191) R.A. Epperly and F.L. Hoadley: "Considerations when applying ASD's in continuous processes", IEEE Transactions on Industry Applications, Vol.33, No.2, pp.389-395 (1997)

(192) K. Pietilainen: "Voltage Sag Ride-Through of AC Drives: Control and Analysis", Doctor of Technology thesis, Stockholm (2005)

(193) G.P. Ramesh: "Enhancement of power quality and energy storage using a three-terminal ultra-capacitor and CCM converter for regenerative controlled electric drives", International Journal of Emerging Research in Management and Technology (2012)

(194) Guide to the Collection and Presentation of Electrical, Electronic and Sensing Component Reliability Data for Nuclear-Power Generating Stations, IEEE Std. 500 (1983)

(195) P. Wikstrom, L.A. Terens, and H. Kobi: "Reliability, availability, and maintainability of high-power variable-speed drive systems", IEEE Transactions on Industry Applications, Vol.36, No.1, pp.231-241 (2000)

(196) T. Yoshino, H. Masuda, H. Hosoda, M. Tsukakoshi, M.A. Mostafa, and L. Ben-Brahim: "High-reliability extra-large motor drives for oil and gas industry", $20137^{\text {th }}$ IEEE GCC Conference and Exhibition (GCC), Doha, pp.159164 (2013)

Lazhar Ben-Brahim (Member) received the B.Sc. and M.Sc. degrees

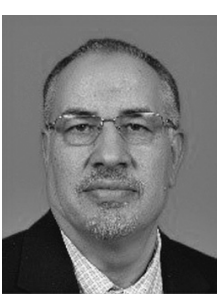

in Electrical Engineering from the National Schoo of Engineers of Tunis, Tunis, Tunisia, in 1985 and 1987, respectively, and the Ph.D. degree in electrical and computer engineering from Yokohama National University, Yokohama, Japan, in 1991. From 1991 to 1997, he was with Toshiba Corporation, Tokyo, Japan. Since September 1997, he has been with Qatar University, where he is currently a Full Professor at the Department of Electrical Engineering. He was the Industrial Electronics Chair for RasGas Company, the Head of the Industrial Technology Department and the Head of the Department of Electrical Engineering. His research interests include power electronics, electric drives, renewable energy, control, and sensors/instrumentation. Dr. Ben-Brahim is a senior member of IEEE and a member of IEE Japan.

Adel Gastli (Non-member) received the B.Sc. Degree in Electrical

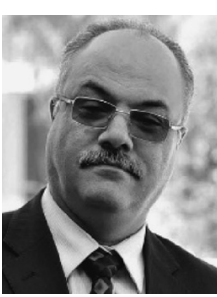
Engineering from National School of Engineers of Tunis, Tunisia in 1985. He worked for two years with the National Institute for Standards and Intellectual Property in the fields of standardization and certification of electric products in Tunisia. He received the M.Sc. and Ph.D. degrees from Nagoya Institute of Technology, Japan in 1990 and 1993, respectively. He joined the R\&D Department at Inazawa Works of Mitsubishi Electric Corporation in Japan from Apr. 1993 to Jul. 1995. He then joined the Electrical and Computer Engineering Department at Sultan Qaboos University, Muscat, Oman, in Aug. 1995. He was Head of the Department from Sept. 2001 to Aug. 2003 and from Sept. 2007 to Aug. 2009. He was appointed the Director of the University Quality Assurance Office from Feb. 2010 to Jan. 2013. In February 2013, he joined the Electrical Engineering Department at Qatar University as a Professor and Kahramaa-Siemens Chair in energy efficiency. He was appointed as the College of Engineering Associate Dean for Academic Affairs from August 2013 till August 2015. His current research interests include power electronics and drives, energy efficiency, renewable energy, and smart grid.
Teruo Yoshino (Fellow) received M.E. degree in electrical engineer-

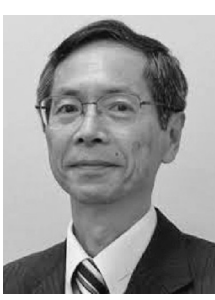
ing from Yokohama National University, Kanagawa, Japan and joined Toshiba in 1978. He has been working for developments on power electronics products for high voltage and high power applications including HVDC and SVC. In 2003, he earned Ph.D. at Yokohama National University. He moved to Toshiba Mitsubishi Electric Industrial Systems Corporation, established also in 2003. There, he works as a senior fellow engineer of power electronics. He is a Fellow

of IEE of Japan.

Tomoki Yokoyama (Member) was born in Hiroshima Prefecture,

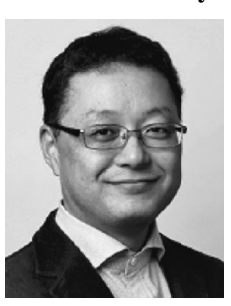
Japan in 1965. He received the B.S., M.S. and Ph.D. degrees in Electrical Engineering from Yokohama National University, Kanagawa, Japan, in 1988 and 1994 respectively. In 1994, he joined Toshiba Corporation Japan. In 1998, he joined Tokyo Denki University. He is currently an associate professor. His research interests are in the areas of advanced control of power electronics. Prof. Yokoyama is a member of the Institute of Electrical Engineers of Japan.

Atsuo Kawamura (Fellow) received the Ph.D. degree in electrical en-

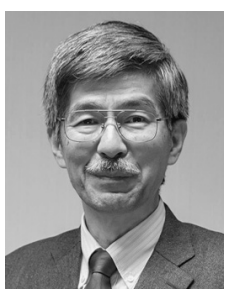
gineering from the University of Tokyo in 1981. After the five-year-stay at the University of MissouriColumbia as a faculty member, he joined Yokohama National University in 1986, and in 1996 he became a professor. From 2013 to 2015 he was a dean of College of Engineering Science and also a dean of Graduate School of Engineering at Yokohama National University. His interests are in the fields of power electronics, digital control, electric vehicles, and biped robotics. He received Transactions Paper Awards from IEEE in 1988, 2001 and 2002, also from IEE of Japan in 1996. Dr. Kawamura is an IEEE Fellow, and also a Fellow of the IEE of Japan. He served as a president of IEEJ/IAS from May 2012 to May 2013. 